\title{
Genetic similarity in a hybrid population of 'Montenegrina' and 'King' mandarins
}

\author{
Eduardo Cesar Brugnara( ${ }^{(1)}$, Marinês Bastianel(2), Roberto Luis Weiler ${ }^{(3)}$ and Sergio Francisco Schwarz ${ }^{(4)}$
}

\begin{abstract}
(1)Empresa de Pesquisa Agropecuária e Extensão Rural de Santa Catarina, Servidão Ferdinando Tusset, Caixa Postal 791, Bairro São Cristóvão, CEP 89801-970 Chapecó, SC, Brazil. E-mail: edubrugnara@ibest.com.br (2)Agência Paulista de Tecnologia do Agronegócio, Centro APTA Citros Sylvio Moreira, Rodovia Anhanguera, Km 158, Caixa Postal 04, CEP 13490-970 Cordeirópolis, SP, Brazil. E-mail: mbastianel@centrodecitricultura.br (3)Universidade Federal do Rio Grande do Sul (UFRGS), Programa de Pós-Graduação em Zootecnia, Avenida Bento Gonçalves, no 7.712, Bairro Agronomia, CEP 91540-000 Porto Alegre, RS, Brazil. E-mail: robertoluisw@yahoo.com.br (4)UFRGS, Departamento de Horticultura e Silvicultura e Programa de Pós-Graduação em Fitotecnia. E-mail: schwarz@ufrgs.br
\end{abstract}

Abstract - The objective of this work was to confirm the hybrids obtained in plants originated from the crossing between the mandarins Citrus deliciosa 'Montenegrina' and C. nobilis 'King', and to estimate the genetic similarity among hybrids, and between each hybrid and its parents. Twenty-three pairs of microsatellite primers were tested. Fourteen of these pairs showed polymorphic bands between parents. Primers CCSM 129 and CCSME 52 were sufficient to identify the 12 nucellar clones observed in the studied population. Genetic similarity analysis of the population (hybrids and parents) showed 0.56 average similarity. Besides the 12 clones of 'Montenegrina' identified, 25 hybrids were found of which D18, C32, D06, C05 and D09 are the more similar to 'Montenegrina'.

Index terms: Citrus deliciosa, Citrus nobilis, hybrid identification, microsatellite markers.

\section{Similaridade genética em uma população de híbridos de tangerineiras 'Montenegrina' e 'King'}

Resumo - O objetivo deste trabalho foi confirmar os híbridos obtidos em plantas originadas do cruzamento entre as tangerineiras Citrus deliciosa 'Montenegrina' e C. nobilis 'King', e estimar a similaridade genética entre os híbridos e entre cada híbrido e seus parentais. Vinte e três pares de iniciadores microssatélites foram testados. Quatorze desses pares apresentaram bandas polimórficas entre os parentais. Os iniciadores CCSM 129 e CCSME 52 foram suficientes para identificar os 12 clones nucelares observados na população estudada. A análise da similaridade genética da população (híbridos e parentais) mostrou similaridade média de 0,56. Além dos 12 clones identificados de 'Montenegrina', foram encontrados 25 híbridos, dos quais D18, C32, D06, C05 e D09 são os mais similares a 'Montenegrina'.

Termos para indexação: Citrus deliciosa, Citrus nobilis, identificação de híbridos, marcadores microssatélites.

\section{Introduction}

The low genetic diversity in mandarin commercial orchards in Brazil limits the yield. In the state of São Paulo there are two important cultivars (Pio et al., 2005). In the state of Rio Grande do Sul, 'Montenegrina', 'Okitsu', 'Caí', 'Ponkan' and 'Pareci' compose almost all the orchards (João, 2004). These cultivars are originated from spontaneous mutations or from individual plant selection. Few cultivars are originated from hybridization (Schwarz, 2009), which is a great opportunity for gene exchange in the citrus group, since interspecific and intergeneric crossings are possible. There is a great variability to be explored within the genus Citrus for the majority of characters.
The use of hybridization in plant breeding increases the genotypical and phenotypical variations, which constitute the foundations for the selection of superior individuals. Citrus breeding programs based on hybridization face some difficulties, such as high parental heterozygosis that results in progenies which are not very similar to their parents, since the observed variance in the parents is not due only to additive effects (inheritable). Furthermore, apomictic reproduction complicates the identification of hybrids, and sterility and incompatibility limit the use of some parents in some combinations. Finally, the juvenility of plants originated from seeds makes it difficult to select for fruit characteristics, since plants take six to eight years to set fruit (Schwarz, 2009). 
Genetic gain success depends on the presence of genetic variability in the species. Different techniques such as morphological evaluation, enzyme, biochemical, and DNA markers can be used to estimate the genetic similarity between plants.

Microsatellite markers (SSR) are repetitions of simple sequences from one to four base pairs amplified by arbitrary primers. This technique allows the use of primers developed for related species (Luro et al., 2008; Cristofani-Yaly et al., 2011). In citrus, microsatellite markers have been used to characterize genetic diversity (Novelli et al., 2006; Jannati et al., 2009; Cristofani-Yaly et al., 2011), to identify hybrids originated by artificial crossings (Bastianel et al., 1998; Scarano et al., 2003), and to perform genetic mapping (Bastianel et al., 2009), among others.

Due to the high heterozygosis of citrus plants, genetic variability is supposed to exist in sexual progenies. Oliveira et al. (2002a), using RAPD markers and plants from the crossing $C$. reticulata Blanco 'Cravo' x C. sinensis (L.) Osb. 'Pêra', observed that the hybrids have different similarity coefficients from the parents and even among themselves. The estimate of similarity between genotypes can help to choose more or less distinct types, and their crossings can lead to higher or lower genetic variation of the progenies (Messmer et al., 1993). Other papers on the estimate of genetic similarity in citrus hybrids have reported the identification of genotypes that are more or less similar to their parents, and have shown the formation of genetic combinations different from those found in the parents (Bastianel et al., 2006; Weiler et al., 2010).

At the Estação Experimental Agronômica of the Universidade Federal do Rio Grande do Sul, there is a population of mandarin seedlings originated from an artificial crossing between $C$. deliciosa Ten. 'Montenegrina' and C. nobilis Lour. 'King' used as the male parent. The crossing aimed to combine the 'Montenegrina' fruit quality with the 'King' fruit size and late maturation in a unique variety, which could increase the harvest period in Brazil and produce fruit with higher quality. The crossing was carried out in 1993. Using RAPD markers, Bastianel et al. (1998) identified 54 new hybrid plants within the progenies of this crossing, and ten others of doubtful hybrid nature due to the limitations of the markers used.
The objective of this work was to confirm the hybrids obtained in plants originated from the crossing between Citrus deliciosa 'Montenegrina' and C. nobilis 'King', and to estimate the genetic similarity among hybrids and between each hybrid and its parents.

\section{Materials and Methods}

The experiment was carried out in 2006, with plants originated from the crossing between 'Montenegrina' (female parent) and 'King', plus the parents. The population was studied by Bastianel et al. (1998) through RAPD markers, and 54 plants were identified as hybrids. In that study, it was impossible to ascertain if ten of the plants were hybrids, due to the limitations of the markers used. These plants are located in Eldorado do Sul, RS, Brazil, at the Universidade Federal do Rio Grande do Sul (UFRGS).

Genomic DNA was extracted from 37 plants, at the UFRGS, Porto Alegre, RS, Brazil, following the methodology described by Doyle \& Doyle (1987) with some modifications. DNA concentration was determined by electrophoresis (1 hour at $120 \mathrm{~V})$, in $0.8 \%$ agarose gel containing $0.5 \mu \mathrm{g} \mathrm{mL}-1$ of ethidium bromide and band comparison with known concentration patterns. The DNA was diluted at $100 \mathrm{ng} \mu \mathrm{L}^{-1}$ and kept in the freezer at $-20^{\circ} \mathrm{C}$. The presence of RNA was observed in the same gel and, when in large amounts, was treated with RNAse.

The amplification reactions, electrophoresis and the gel revelations were done at the biotechnology laboratory of the Centro Avançado de Pesquisa Tecnológica do Agronegócio de Citros Sylvio Moreira, Instituto Agronômico, Cordeirópolis, SP, Brazil. The reactions were prepared in $25 \mu \mathrm{L}$ volume containing one unit of the Taq polymerase enzyme, $10 \mathrm{mmol}$ of dNTP mix (dATP, dTTP, dCTP, dGTP), $2.5 \mu \mathrm{L}$

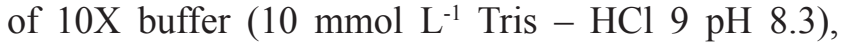
$50 \mathrm{mmol} \mathrm{L}^{-1}$ of $\mathrm{MgCl}_{2}, 4$ pmol of each primer ( $\mathrm{R}$ and L), $100 \mathrm{ng}$ of genomic DNA and autoclaved $\mathrm{H}_{2} \mathrm{O}$. The amplification protocol was 30 cycles of: $94^{\circ} \mathrm{C}$ for $30 \mathrm{~s} ; 65-56^{\circ} \mathrm{C}$ for $30 \mathrm{~s}$ (touchdown $0.3^{\circ} \mathrm{C}$ at each cycle); and $72^{\circ} \mathrm{C}$ for $5 \mathrm{~s}$; and, at the end of the 30 cycles, at $72^{\circ} \mathrm{C}$ for $5 \mathrm{~min}$. To visualize the amplified fragments, the samples underwent electrophoresis in agarose or acrylamide gels. When in agarose, $4 \%$ gels were used. They were prepared with TAE $1 \mathrm{X}$ buffer (0.04 mol L-1, tris acetate, $1 \mathrm{mmol} \mathrm{L}^{-1}$ of EDTA), 
and ethidium bromide $\left(0.5 \mu \mathrm{g} \mathrm{mL}^{-1}\right)$, electrophoresis $(120 \mathrm{~V})$ for two hours in TAE $1 \mathrm{X}$ buffer, after adding $8 \mu \mathrm{L}$ of the reaction, and the revelation was done at UV light. When the agarose gels did not separate the bands clearly, acrylamide gels were used, prepared with $1.5 \mathrm{~mL}$ of TAE buffers $10 \mathrm{X}, 8 \mathrm{~mL}$ of acrylamide $29: 1$ (acrylamide:bis-acrylamide), $350 \mu \mathrm{L}$ of ammonium persulfate, $25 \mu \mathrm{L}$ of temed, and $20.12 \mathrm{~mL}$ of bidistilled autoclaved water. Six $\mu \mathrm{L}$ of each reagent were applied, and gel underwent an electric current of $80 \mathrm{~V}$ for 2.5 hours in TAE $1 \mathrm{X}$ buffer. Fragments were visualized by silver staining as follows: gels were placed in $70 \%$ ethanol for $10 \mathrm{~min}$ followed by two washings in distilled water; $3 \mathrm{~min}$ in $1 \%$ nitric acid solution and, then, by two washings; $20 \mathrm{~min}$ in $0.2 \%$ silver nitrate, followed by three washings in distilled water, followed by the application of the revealing solution $\left(100 \mathrm{~mL} \mathrm{CaCO}_{3}\right.$ $3 \%$ with $54 \mu \mathrm{L}$ of formaldehyde) until the appearance of the bands, when $5 \%$ acetate was applied for $30 \mathrm{~s}$ to 5 min to interrupt the reaction.

The primers used in the present study were identified from the sweet orange [C. sinensis (L.) Osb.] genome (Novelli et al., 2006), and express sequences (ESTs) of citrus (Palmieri et al., 2007). Twenty-three pairs of primers were tested, and those which amplified at least one different band between 'Montenegrina' and 'King' were analyzed on the progeny (Table 1). A DNA sample of 'Pêra' sweet orange was included in the process as a control, since some primers were identified in its genome.

Table 1. Primers used in the generation of SSR molecular markers in the 'Montenegrina' $x$ 'King' population, source, number of amplified alleles in the population, size of the created fragments, and type of gel used in the revelation.

\begin{tabular}{llll}
\hline Primer & \multicolumn{1}{c}{ Source } & \multicolumn{1}{c}{ Amplified alleles } & \multicolumn{1}{c}{ Gel } \\
\hline CCSM 1 & Novelli et al. 2006 & $2(176$ and $153 \mathrm{bp})$ & $8 \%$ Acrylamide \\
CCSM 4 & Novelli et al. 2006 & $2(93$ and $97 \mathrm{bp})$ & $8 \%$ Acrylamide \\
CCSM 6 & Novelli et al. 2006 & $3(236,227$ and $210 \mathrm{bp})$ & $4 \%$ Agarose \\
CCSM 19 & Novelli et al. 2006 & $2(267$ and $249 \mathrm{bp})$ & $4 \%$ Agarose \\
CCSM 25 & Novelli et al. 2006 & $3(156,127$ and $120 \mathrm{bp})$ & $8 \%$ Acrylamide \\
CCSM 35 & Novelli et al. 2006 & $2(197$ and $167 \mathrm{bp})$ & $4 \%$ Acrylamide \\
CCSM 119 & Novelli et al. 2006 & $3(37,48$ and $51 \mathrm{bp})$ & $4 \%$ Agarose \\
CCSM 129 & Novelli et al. 2006 & $3(173,157$ and $150 \mathrm{bp})$ & $8 \%$ Acrylamide \\
CCSM 147 & Novelli et al. 2006 & $3(133,117$ and $110 \mathrm{bp})$ & $8 \%$ Acrylamide \\
CCSM 150 & Novelli et al. 2006 & $3(165,159$ and $146 \mathrm{bp})$ & $4 \%$ Agarose \\
CCSM 170 & Novelli et al. 2006 & $2(189$ and $167 \mathrm{bp})$ & $8 \%$ Acrylamide \\
CCSMEc 11 & Palmieri et al. 2007 & $3(153,139$ and $135 \mathrm{bp})$ & $8 \%$ Acrylamide \\
CCSME 05 & Palmieri et al. 2007 & $3(150,145$ and $140 \mathrm{bp})$ & $8 \%$ Acrylamide \\
CCSME 52 & Palmieri et al. 2007 & $4(231$ and $250 \mathrm{bp})$ & $8 \%$ Acrylamide \\
\hline
\end{tabular}

The markers were evaluated by attributing the score 1 for the presence of polymorphic band and 0 for the absence, in each hybrid and parent. Calculation of similarity was done using the Jaccard coefficient (Cruz \& Carneiro, 2003). Grouping was done by the UPGMA method, and the results were used in the construction of a dendrogram. The software NTSYS was used in the analysis. Cophenetic correlation (Mantel's coefficient) was applied in order to evaluate the fidelity between dendrograms and similarity matrixes.

\section{Results and Discussion}

Out of the twenty-three pairs of primers tested, fourteen $(60 \%)$ showed polymorphism between 'Montenegrina' and 'King' (Table 1). This proportion is higher than the $28 \%$ observed by Weiler et al. (2010), who worked with the 'Montenegrina' and 'Clementina Fina' (C. clementina Hort. Ex Tan.) mandarins. This difference can be due to the nonrandom selection of primers, since selection was based on previous experience of the researchers of the Centro de Citricultura and on Weiler et al. (2010), and the genetic similarity between 'Montenegrina' and 'King' is the same as the one between 'Montenegrina' and 'Clementina Fina' (Koehler-Santos et al., 2003).

The 14 primers utilized in this paper generated 38 bands in the hybrid population of 'Montenegrina' $\mathrm{x}$ 'King', with emphasis on the CCSME 52 that generated four alleles, two in each parental (Table 1). The markers allowed for the differentiation of all hybrids in the population, with 0.86 maximum similarity between the D32 and C08 hybrids (Table 3).

After the analyses of the 37 plants supposedly originated from the 'Montenegrina' x 'King' crossing, using the 14 primers (Table 1), 12 individuals were identified as 'Montenegrina' clones, and the rest as hybrids (Table 2). Primers CCSM 129 (Figure 1) and

Table 2. List of nucellar clones and hybrids found in the population originated from artificial crossing of 'Montenegrina' x 'King' mandarins.

\begin{tabular}{lc}
\hline Material & Genotype \\
\hline Nucellar clones & $\mathrm{C} 14, \mathrm{C} 15, \mathrm{C} 19, \mathrm{C} 29, \mathrm{D} 11, \mathrm{D} 14, \mathrm{D} 19, \mathrm{D} 20, \mathrm{D} 24, \mathrm{D} 28$, \\
& $\mathrm{D} 30$ and D31 \\
Hybrids & $\mathrm{C} 01, \mathrm{C} 02, \mathrm{C} 05, \mathrm{C} 07, \mathrm{C} 08, \mathrm{C} 10, \mathrm{C} 17, \mathrm{C} 18, \mathrm{C} 22, \mathrm{C} 23$, \\
& $\mathrm{C} 24, \mathrm{C} 26, \mathrm{C} 28, \mathrm{C} 32, \mathrm{D} 03, \mathrm{D} 06, \mathrm{D} 08, \mathrm{D} 09, \mathrm{D} 16, \mathrm{D} 18$, \\
& $\mathrm{D} 21, \mathrm{D} 22, \mathrm{D} 25, \mathrm{D} 29$ and D32 \\
\hline
\end{tabular}


CCSME 52 used alone were sufficient to identify the 12 clones, which showed the same alleles as 'Montenegrina' and none of 'King'. Ten nucellar clones were expected, since they were added to the hybrid population at planting in the orchard, due to the uncertainty on the reliability of the RAPD marker data.

The RAPD technique utilized by Bastianel et al. (1998) in the identification of hybrids in this crossing has repeatability problems, probably due to the fact that low temperatures of annealing were used in the polymerase chain reaction, which makes the annealing less specific than that of the microsatellites. In fact, due to their codominant nature, SSR markers are more indicated for this type of study, as it has been shown that these markers were efficient in the identification of male genitors of progenies in Eucalyptus (Grattapaglia et al., 2004). Bastianel et al. (1998) identified 54 hybrids among 202 individuals $(26,7 \%)$ generated from embryos cultivated in vitro and extracted from 'Montenegrina' pollinated with 'King', using four RAPD primers. As shown in the present work, the use of only one microsatellite primer, CCSM 129 or CCSME 52, would certainly result in a greater efficiency with reduced time and procedure costs.

Similarity between 'Montenegrina' and 'King' was of 0.31 (Table 3), a result very similar to the one observed by Koehler-Santos et al. (2003). The grouping by genetic similarity (Figure 2) divided the population into three groups with lower similarity between them than the average (0.56); the first one contained 'Montenegrina' and 12 hybrids; the second one contained 'King' and seven hybrids; and the third group had six hybrids which were more distant from both parentals than the parentals among themselves (Figure 2). The last group is not observed in the similarity matrix (Table 3 ).

Higher distances from hybrids to parents than between parents were observed by Weiler et al. (2010), in a hybrid population of 'Clementina Fina' $\mathrm{x}$ 'Montenegrina', also using SSR markers, and by Bastianel et al. (2006) with 'Murcott' x 'Pêra'. However, tangerine hybrids from 'Cravo' mandarin $\mathrm{x}$ 'Pêra' sweet orange did not behave in the same manner, and formed no significant groups, possibly due to the great number of markers used and the lack of connection between them (Oliveira et al., 2002b).

Table 3. Jaccard index between 'Montenegrina' (M) mandarin and the progenies of its crossing with 'King' (K) mandarin.

\begin{tabular}{|c|c|c|c|c|c|c|c|c|c|c|c|c|c|c|c|c|c|c|c|c|c|c|c|c|c|c|}
\hline Genotype & M & $\mathrm{K}$ & $\mathrm{C} 01$ & $\mathrm{C} 02$ & $\mathrm{C} 05$ & $\mathrm{C} 07$ & $\mathrm{C} 08$ & $\mathrm{C} 10$ & $\mathrm{C} 17$ & C18 & $\mathrm{C} 22$ & $\mathrm{C} 23$ & $\mathrm{C} 24$ & $\mathrm{C} 26$ & $\mathrm{C} 28$ & C32 & D03 & D06 & D08 & D09 & D16 & D18 & D21 & D22 & D25 & D29 \\
\hline $\mathrm{K}$ & 0.31 & & & & & & & & & & & & & & & & & & & & & & & & & \\
\hline $\mathrm{C} 01$ & 0.51 & 0.61 & & & & & & & & & & & & & & & & & & & & & & & & \\
\hline $\mathrm{C} 02$ & 0.20 & 0.59 & 0.59 & & & & & & & & & & & & & & & & & & & & & & & \\
\hline $\mathrm{C} 05$ & 0.62 & 0.57 & 0.42 & 0.52 & & & & & & & & & & & & & & & & & & & & & & \\
\hline $\mathrm{C} 07$ & 0.58 & 0.58 & 0.58 & 0.56 & 0.47 & & & & & & & & & & & & & & & & & & & & & \\
\hline $\mathrm{C} 08$ & 0.20 & 0.64 & 0.82 & 0.73 & 0.41 & 0.61 & & & & & & & & & & & & & & & & & & & & \\
\hline $\mathrm{C} 10$ & 0.53 & 0.58 & 0.75 & 0.61 & 0.48 & 0.60 & 0.72 & & & & & & & & & & & & & & & & & & & \\
\hline $\mathrm{C} 17$ & 0.57 & 0.47 & 0.47 & 0.55 & 0.63 & 0.39 & 0.50 & 0.53 & & & & & & & & & & & & & & & & & & \\
\hline $\mathrm{C} 18$ & 0.58 & 0.53 & 0.58 & 0.56 & 0.70 & 0.50 & 0.47 & 0.65 & 0.64 & & & & & & & & & & & & & & & & & \\
\hline $\mathrm{C} 22$ & 0.50 & 0.57 & 0.47 & 0.69 & 0.61 & 0.44 & 0.60 & 0.58 & 0.73 & 0.57 & & & & & & & & & & & & & & & & \\
\hline $\mathrm{C} 23$ & 0.52 & 0.62 & 0.52 & 0.50 & 0.63 & 0.48 & 0.50 & 0.35 & 0.51 & 0.48 & 0.50 & & & & & & & & & & & & & & & \\
\hline $\mathrm{C} 24$ & 0.53 & 0.58 & 0.53 & 0.51 & 0.68 & 0.55 & 0.56 & 0.37 & 0.53 & 0.54 & 0.57 & 0.70 & & & & & & & & & & & & & & \\
\hline $\mathrm{C} 26$ & 0.48 & 0.63 & 0.58 & 0.51 & 0.53 & 0.60 & 0.56 & 0.78 & 0.48 & 0.71 & 0.64 & 0.44 & 0.45 & & & & & & & & & & & & & \\
\hline $\mathrm{C} 28$ & 0.58 & 0.53 & 0.44 & 0.61 & 0.80 & 0.50 & 0.47 & 0.50 & 0.57 & 0.60 & 0.57 & 0.53 & 0.65 & 0.50 & & & & & & & & & & & & \\
\hline $\mathrm{C} 32$ & 0.65 & 0.51 & 0.48 & 0.67 & 0.73 & 0.50 & 0.56 & 0.45 & 0.53 & 0.55 & 0.62 & 0.59 & 0.71 & 0.45 & 0.84 & & & & & & & & & & & \\
\hline D03 & 0.48 & 0.64 & 0.54 & 0.62 & 0.58 & 0.67 & 0.68 & 0.56 & 0.55 & 0.47 & 0.71 & 0.50 & 0.72 & 0.56 & 0.56 & 0.56 & & & & & & & & & & \\
\hline D06 & 0.64 & 0.54 & 0.59 & 0.62 & 0.60 & 0.67 & 0.62 & 0.51 & 0.45 & 0.56 & 0.53 & 0.55 & 0.72 & 0.47 & 0.61 & 0.78 & 0.62 & & & & & & & & & \\
\hline D08 & 0.48 & 0.62 & 0.64 & 0.65 & 0.42 & 0.57 & 0.74 & 0.55 & 0.48 & 0.36 & 0.57 & 0.69 & 0.53 & 0.48 & 0.48 & 0.58 & 0.65 & 0.56 & & & & & & & & \\
\hline D09 & 0.61 & 0.48 & 0.55 & 0.62 & 0.53 & 0.50 & 0.57 & 0.37 & 0.61 & 0.37 & 0.57 & 0.65 & 0.67 & 0.32 & 0.61 & 0.73 & 0.57 & 0.64 & 0.67 & & & & & & & \\
\hline D16 & 0.58 & 0.53 & 0.80 & 0.60 & 0.52 & 0.55 & 0.70 & 0.57 & 0.43 & 0.45 & 0.52 & 0.57 & 0.64 & 0.50 & 0.58 & 0.64 & 0.62 & 0.62 & 0.67 & 0.73 & & & & & & \\
\hline D18 & 0.70 & 0.45 & 0.52 & 0.63 & 0.50 & 0.74 & 0.50 & 0.48 & 0.47 & 0.53 & 0.48 & 0.50 & 0.52 & 0.52 & 0.57 & 0.59 & 0.48 & 0.65 & 0.47 & 0.64 & 0.56 & & & & & \\
\hline D21 & 0.50 & 0.64 & 0.59 & 0.48 & 0.65 & 0.67 & 0.48 & 0.51 & 0.45 & 0.61 & 0.54 & 0.60 & 0.72 & 0.67 & 0.61 & 0.56 & 0.73 & 0.62 & 0.55 & 0.52 & 0.68 & 0.58 & & & & \\
\hline D22 & 0.50 & 0.53 & 0.61 & 0.68 & 0.34 & 0.55 & 0.64 & 0.52 & 0.55 & 0.52 & 0.63 & 0.53 & 0.50 & 0.55 & 0.36 & 0.50 & 0.51 & 0.59 & 0.61 & 0.63 & 0.55 & 0.64 & 0.47 & & & \\
\hline D25 & 0.47 & 0.60 & 0.52 & 0.58 & 0.55 & 0.62 & 0.54 & 0.44 & 0.63 & 0.44 & 0.61 & 0.61 & 0.68 & 0.47 & 0.62 & 0.57 & 0.81 & 0.50 & 0.68 & 0.70 & 0.64 & 0.55 & 0.75 & 0.53 & & \\
\hline D29 & 0.47 & 0.62 & 0.51 & 0.64 & 0.53 & 0.53 & 0.64 & 0.69 & 0.56 & 0.63 & 0.69 & 0.42 & 0.48 & 0.81 & 0.63 & 0.58 & 0.59 & 0.46 & 0.52 & 0.39 & 0.48 & 0.50 & 0.54 & 0.53 & 0.55 & \\
\hline D32 & 0.42 & 0.76 & 0.70 & 0.68 & 0.48 & 0.62 & 0.86 & 0.61 & 0.54 & 0.47 & 0.60 & 0.60 & 0.61 & 0.56 & 0.43 & 0.51 & 0.73 & 0.57 & 0.71 & 0.52 & 0.62 & 0.44 & 0.53 & 0.62 & 0.58 & 0.59 \\
\hline
\end{tabular}


The dendrogram was not a good representation of the similarity matrix, since the obtained Mantel coefficient was 0.62 , which is below the critical value of 0.8 normally accepted (Sokal \& Rohlf, 1962). This

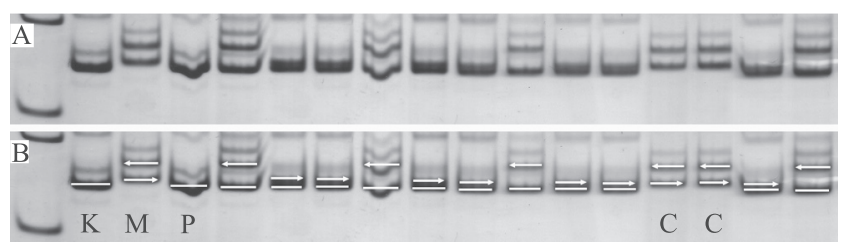

Figure 1. Amplification of the CCSM 129 primer in $8 \%$ polyacrylamide gel (A) and the interpretation of this amplification (B). The first lane is a marker, $\mathrm{K}$ for 'King', $\mathrm{M}$ for 'Montenegrina', P for 'Pêra' sweet orange (used as control), and the other lanes are a part of the studied progenies. White bars and arrows represent alleles. Lanes marked with a "C" have only alleles from $\mathrm{M}$, so they represent nucellar clones of 'Montenegrina'. indicates that there is a great amount of occasional variation, which means a poor population structure. Rodrigues \& Diniz-Filho (1998) suggest that the UPGMA clustering method works better in large matrixes, requiring verification by the cophenetic correlation (r). The UPGMA clustering obtained by Rodrigues et al. (2002) did not reach a high $r$, along with other ranking methods.

The generated information (Table 3 ) estimates that D18, C32, D06, C05 and D09 hybrids are genetically more similar to 'Montenegrina' and therefore more indicated for backcrossing with this parental for the creation of new genotypes phenotypically similar to it, considering that this is the main goal of the genetic breeding program from which this work is part. Oliveira et al. (2002b) easily selected hybrids more similar to the parentals using RAPD markers.

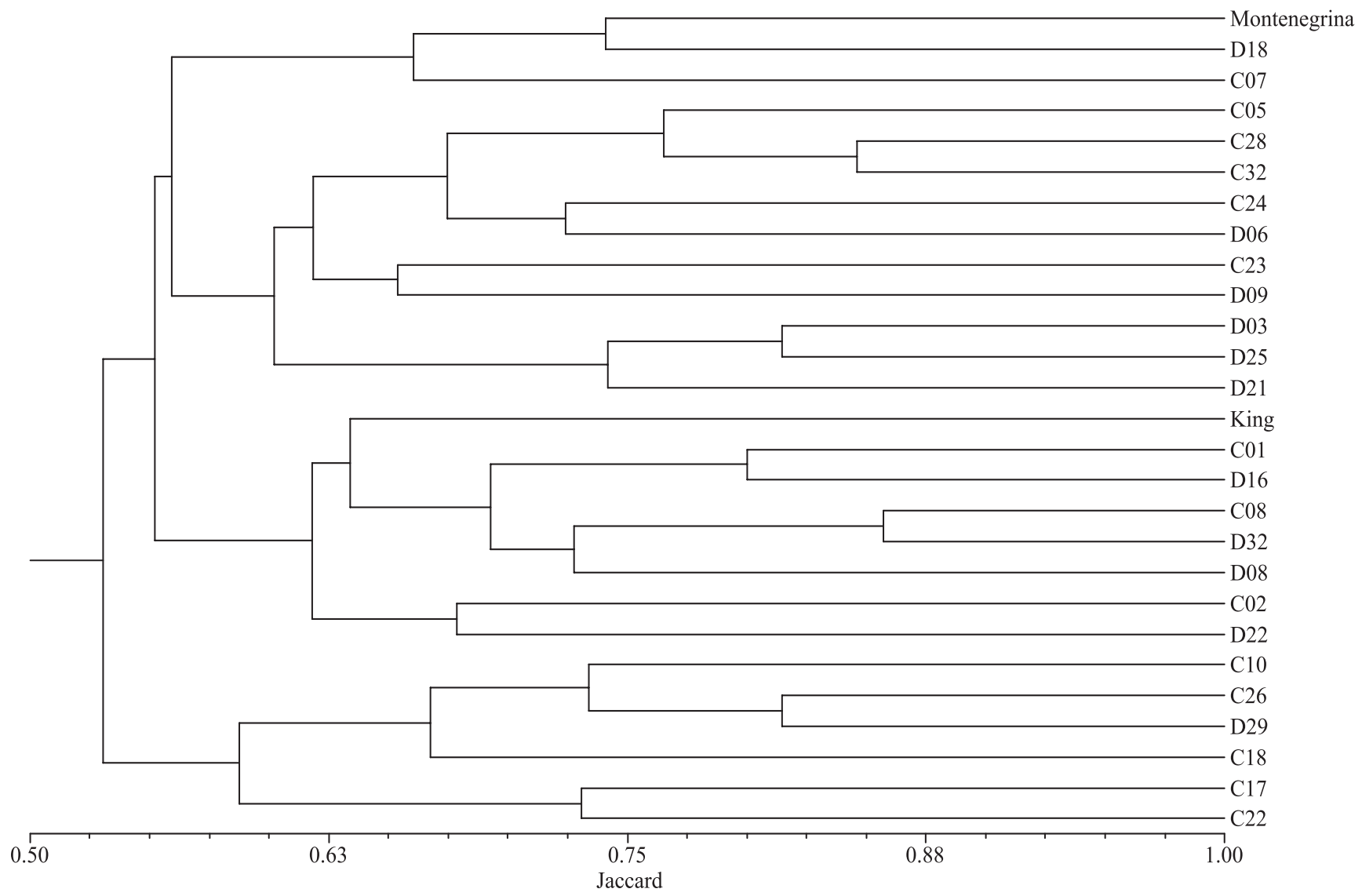

Figure 2. Genetic similarity between hybrids and parents of the crossing between 'Montenegrina' and 'King' mandarins. 


\section{Conclusions}

1. The CCSM 129 and CCSME 52 markers are able of differentiating the hybrids from the female parent 'Montenegrina' and, therefore, they can be used in isolation for the identification of 'Montenegrina' $\mathrm{x}$ 'King' hybrids.

2. The hybrids D18, C32, D06, C05 and D09 are more similar to 'Montenegrina' than the others.

\section{Acknowledgements}

To Coordenação de Aperfeiçoamento de Pessoal de Nível Superior, Conselho Nacional de Desenvolvimento Científico e Tecnológico and Fundação de Amparo à Pesquisa do Estado do Rio Grande do Sul, for financial support and scholarships; and to Centro Apta Citros Sylvio Moreira, for laboratorial and technical support.

\section{References}

BASTIANEL, M.; CRISTOFANI-YALY, M.; OLIVEIRA, A.C. de; FREITAS-ASTÚA, J.; GARCIA, A.A.F.; RESENDE, M.D.V. de; RODRIGUES, V.; MACHADO, M.A. Quantitative trait loci analysis of citrus leprosis resistance in an interspecific backcross family of (Citrus reticulata Blanco $\times$ C. sinensis $\mathrm{L}$. Osbeck $) \times C$. sinensis L. Osb. Euphytica, v.169, p.101-111, 2009.

BASTIANEL, M.; OLIVEIRA, A.C. de; CRISTOFANI, M.; MACHADO, M.A. Diversidade genética entre híbridos de laranja-doce e tangor 'Murcott' avaliada por fAFLP e RAPD. Pesquisa Agropecuária Brasileira, v.41, p.779-784, 2006.

BASTIANEL, M.; SCHWARZ, S.F.; COLETA FILHO, H.D.; LIN, L.L.; MACHADO, M.; KOLLER, O.C. Identification of zygotic and nucellar tangerine seedlings (Citrus spp.) using RAPD. Genetics and Molecular Biology, v.21, p.123-127, 1998.

CRISTOFANI-YALY, M.; NOVELLI, V.M.; BASTIANEL, M.; MACHADO, M.A. Transferability and level of heterozygosity of microsatellite markers in Citrus species. Plant Molecular Biology Reporter, v.29, p.418-423, 2011.

CRUZ, C.D.; CARNEIRO, P.C.S. Modelos biométricos aplicados ao melhoramento genético. Viçosa: UFV, 2003. v.2, $585 \mathrm{p}$.

DOYLE, J.J.; DOYLE, J.L. A rapid DNA isolation method for small quantities of fresh tissues. Phytochemical Bulletin, v.19, p.11-15, 1987.

GRATTAPAGLIA, D.; RIBEIRO, V.J.; REZENDE, G.D.S.P. Retrospective selection of elite parent trees using paternity testing with microsatellite markers: an alternative short term breeding tactic for Eucalyptus. Theoretical and Applied Genetics, v.109, p.192-1999, 2004.
JANNATI, M.; FOTOUHI, R.; POURJAN ABAD, A.; SALEHI, Z. Genetic diversity analysis of Iranian citrus varieties using micro satellite (SSR) based markers. Journal of Horticulture and Forestry, v.1, p.120-125, 2009.

JOÃO, P.L. (Coord.). Levantamento de fruticultura comercial do Rio Grande do Sul. Porto Alegre: Emater: ASCAR, 2004. 89 p.

KOEHLER-SANTOS, P.; DORNELLES, A.L.C.; FREITAS, L.B. de. Characterization of mandarin citrus germplasm from Southern Brazil by morphological and molecular analyses. Pesquisa Agropecuária Brasileira, v.38, p.797-806, 2003.

LURO, F.L.; COSTANTINO, G.; TEROL, J.; ARGOUT, X.; ALLARIO, T.; WINCKER, P.; TALON, M.; OLLITRAULT, P.; MORILLON, R. Transferability of the EST-SSRs developed on Nules clementine (Citrus clementina Hort. ex Tan.) to other Citrus species and their effectiveness for genetic mapping. BMC Genomics, v.9, 2008. Doi:10.1186/1471-2164-9-287.

MESSMER, M.M.; MELCHINGER, A.E.; HERRMANN, R.G.; BOPPENMAIER, J. Relationships among early European maize inbreds. 2. Comparison of pedigree and RFLP data. Crop Science, v.33, p.944-950, 1993.

NOVELLI, V.M.; CRISTOFANI, M.; SOUZA.A.A.; MACHADO, M.A. Development and characterization of polymorphic microsatellite markers for the sweet orange (Citrus sinensis L. Osbeck). Genetics and Molecular Biology, v.29, p.90-96, 2006.

OLIVEIRA, A.C. de; GARCIA, A.N.; CRISTOFANI, M.; MACHADO, M.A. Identification of citrus hybrids through the combination of leaf apex morphology and SSR markers. Euphytica, v.128, p.397-403, 2002a.

OLIVEIRA, R.P. de; CRISTOFANI, M.; AGUILAR-VILDOSO, C.I.; MACHADO, M.A. Diversidade genética entre híbridos de tangerina 'Cravo' e laranja 'Pêra'. Pesquisa Agropecuária Brasileira, v.37, p.479-484, 2002b.

PALMIERI, D.A.; NOVELLI, V.M.; BASTIANEL, M.; CRISTOFANI-YALY, M.; ASTÚA-MONGE, G.; CARLOS, E.F.; OLIVEIRA, A.C. de; MACHADO, M.A. Frequency and distribution of microsatellites from ESTs of citrus. Genetics and Molecular Biology, v.30 p.1009-1018, 2007.

PIO, R.M.; FIGUEIREDO, J.O.; STUCHI, E.S.; CARDOSO, S.A.B. Variedades copas. In: MATTOS JUNIOR, D.; DE NEGRI, J.D.; PIO, R.M.; POMPEU JUNIOR, J. (Ed.). Citros. Campinas: Instituto Agronômico de Campinas: Fundag, 2005. p.37-104.

RODRIGUES, F.M.; DINIZ-FILHO J.A.F. Hierarchical structure of genetic distances: effects of matrix size, spatial distribution and correlation structure among gene frequencies. Genetics and Molecular Biology, v.21, p.233-240, 1998.

RODRIGUES, F.M.; DINIZ-FILHO, J.A.F.; BATAUS, L.A.M.; BASTOS, R.P. Hypothesis testing of genetic similarity based on RAPD data using Mantel tests and model matrices. Genetics and Molecular Biology, v.25, p.435-439, 2002.

SCARANO, M.T.; TUSA, N.; ABBATE, L.; LUCRETTI, S.; NARDI, L.; FERRANTE, S. Flow cytometry, SSR and modified AFLP markers for the identification of zygotic plantlets in backcrosses between 'Femminello' lemon cybrids ( $2 n$ and $4 n$ ) and 
a diploid clone of 'Femminello' lemon (Citrus limon L. Burm. F.) tolerant to mal secco disease. Plant Science, v.164, p.1009-1017, 2003.

SCHWARZ, S.F. Melhoramento genético e variedades. In: KOLLER, O.C. (Ed.). Citricultura: cultura de tangerineiras: tecnologia de produção, pós-colheita e industrialização. Porto Alegre: Rigel, 2009. p.35-48.
SOKAL, R.R.; ROHLF, F.J. The comparison of dendrograms by objective methods. Taxon, v.11, p.33-40, 1962.

WEILER, R.L.; BRUGNARA, E.C.; SCHWARZ, S.F.; BASTIANEL, M.; MACHADO, M.A.; SCHIFINO-WITTMANN, M.T. Caracterização molecular de uma progênie de tangerineira 'Clementina Fina' e 'Montenegrina'. Ciência Rural, v.40, p.1523-1529, 2010.

Received on November 7, 2011 and accepted on July 18, 2012 